\title{
Seismic evidence for arc segmentation, active magmatic intrusions and syn-rift fault system in the northern Ryukyu volcanic arc
}

\author{
Ryuta Arai $^{1 *}{ }^{*}$, Shuichi Kodaira ${ }^{1}$, Tsutomu Takahashi $^{1}$, Seiichi Miura ${ }^{1}$ and Yoshiyuki Kaneda ${ }^{2}$
}

\begin{abstract}
Tectonic and volcanic structures of the northern Ryukyu arc are investigated on the basis of multichannel seismic (MCS) reflection data. The study area forms an active volcanic front in parallel to the non-volcanic island chain in the eastern margin of the Eurasian plate and has been undergoing regional extension on its back-arc side. We carried out a MCS reflection experiment along two across-arc lines, and one of the profiles was laid out across the Tokara Channel, a linear bathymetric depression which demarcates the northern and central Ryukyu arcs. The reflection image reveals that beneath this topographic valley there exists a 3-km-deep sedimentary basin atop the arc crust, suggesting that the arc segment boundary was formed by rapid and focused subsidence of the arc crust driven by the arc-parallel extension. Around the volcanic front, magmatic conduits represented by tubular transparent bodies in the reflection images are well developed within the shallow sediments and some of them are accompanied by small fragments of dipping seismic reflectors indicating intruded sills at their bottoms. The spatial distribution of the conduits may suggest that the arc volcanism has multiple active outlets on the seafloor which bifurcate at crustal depths and/or that the location of the volcanic front has been migrating trenchward over time. Further distant from the volcanic front toward the back-arc (> $30 \mathrm{~km}$ away), these volcanic features vanish, and alternatively wide rift basins become predominant where rapid transitions from normal-fault-dominant regions to strike-slip-fault-dominant regions occur. This spatial variation in faulting patterns indicates complex stress regimes associated with arc/back-arc rifting in the northern Okinawa Trough.
\end{abstract}

Keywords: Continental rift, Volcanic arc, Back-arc basin, Seismic reflection, Magma intrusion, Fault development

\section{Introduction}

The northwestern Pacific region is bounded by several island arcs and provides an appropriate field for studying evolution of continental lithospheres associated with oceanic plate subduction, arc volcanism and back-arc spreading/rifting. The Ryukyu arc in southwest Japan, which was originally located on the eastern flank of the Asian continent, now has formed an arc system associated with the subduction of the Philippine Sea plate at the Ryukyu Trench and the back-arc rifting along the Okinawa Trough (Fig. 1). Early and recent active-source

\footnotetext{
${ }^{*}$ Correspondence: ryuta@jamstec.go.jp

${ }^{1}$ Research and Development Center for Earthquake and Tsunami, Japan Agency for Marine-Earth Science and Technology, 3173-25 Showa-mach Kanazawa-ku, Yokohama, Kanagawa 236-0001, Japan

Full list of author information is available at the end of the article
}

seismic surveys confirmed that despite having been stretched through the rifting process, the Ryukyu arc exhibits structural characteristics of typical continental lithospheres, such as thick felsic upper crust with $\mathrm{P}$ wave velocities of $\sim 6.0 \mathrm{~km} / \mathrm{s}$, ensuring that the Ryukyu arc still preserves original continental materials and is thus essentially characterized as a continental arc (Murauchi et al. 1968; Iwasaki et al. 1990; Arai et al. 2016, 2017a, b; Nishizawa et al. 2017) (Fig. 1c). On the other hand, the Ryukyu arc also shows several unusual features differing from other ocean-continent convergent margins: For example, the Ryukyu arc has not experienced typical mountain building in its tectonic history and the most parts currently reside under water as a consequence of regional subsidence since the Miocene time (Letouzey and Kimura 1985). The unique tectonic setting of the 
Ryukyu arc enables us to examine the variation in arc growth processes in these environments.

The Ryukyu arc is geographically subdivided into three segments (northern, central and southern) by two bathymetric depressions running in the arc-perpendicular direction known as the Tokara Channel and the Kerama Gap (Konishi 1965; Kobayashi 1985). Bathymetric data show that these tectonic boundaries form wide acrossarc valleys which are roughly $1 \mathrm{~km}$ deeper than the adjacent arc segments (Fig. 1). Although they are thought to be a key to characterize the architecture and the subsidence history of the overall Ryukyu arc, structure and tectonic controls on the arc deformation there remains unclarified yet. Another subject of debate is that active volcanoes are unevenly distributed along this arc, and the highest density occurs in the northern part: The northern Ryukyu volcanic arc, including the Kikai caldera (which has caused one of the deadliest volcanic disasters in Japanese history) and the Suwanose Island (which caused multiple eruptions in 2015), is one of the most active volcanic areas in Japan (Machida and Arai 1978; Yokose et al. 2010) (Fig. 1b). It is also intriguing that the volcanic front defined by a series of Quaternary volcanic centers is aligned parallel to but topographically separated from the non-volcanic part of the arc (Fig. 1b). Even though the potential volcanic hazards and resultant social relevance are significant, these active volcanoes are located either at less-populated remote islands or below the sea level with sparse geophysical observation networks. The geographical disadvantage makes it difficult to document their geological background, and their natures are still poorly constrained. A full understanding of these magmatic systems requires large-scale close-in observations of subsurface structures.

To improve our understanding of the tectonic and volcanic systems in the northern Ryukyu arc, we carried out a multichannel seismic (MCS) reflection experiment along two across-arc profiles in 2015-2016 (Fig. 1). The first result from this experiment showed an anomalous subduction system at the northern Ryukyu trench caused by the buoyant oceanic lithosphere of the Amami Plateau (Arai et al. 2017b). In this contribution, we use unpublished MCS reflection data from the same experiment to focus on the detailed arc structure within the overriding plate. Based on several lines of evidence for subseafloor structures, we present new constraints on the history of arc segmentation and the ongoing rifting process in the back-arc. In addition, we show evidence for magmatic intrusions into shallow sediments in the proximity of the volcanic front. These results will help us understand how the arc volcanism has developed in the process of arc/ back-arc rifting.

\section{Geological background}

Associated with the northwestward subduction of the Philippine Sea plate, the Ryukyu subduction zone forms a 1200-km-long arc/back-arc system along the eastern margin of the Eurasian plate. Interestingly, despite the active plate subduction along the entire Ryukyu Trench, arc volcanism has been poorly developed over the Ryukyu arc and thus it is essentially characterized as a "non-volcanic" arc. In the northern part of Ryukyu, a series of active volcanoes do occur, but they are situated over $20 \mathrm{~km}$ away from the easterly non-volcanic island chain and lie within the back-arc basin (Japan Meteorological Agency 2013; Fig. 1). As evidenced from bathymetric data of the northern Ryukyu, abundant subaerial/ submarine volcanic edifices with a cone-shaped geometry are widely distributed on the back-arc side of the volcanic front, but such volcanic ridges are scarcely observed on the forearc side (Yokose et al. 2010; Fig. 2). The linear distribution of active volcanoes terminates at the central Ryukyu arc, and only one active volcano is recognized in the southern Ryukyu. The presence/absence of active volcanoes seems roughly correlated with the structural variation of the incoming Philippine Sea plate: The northern part of the plate consists of large-scale buoyant oceanic plateaus (Amami Plateau, Daito Ridge, and Oki-Daito Ridge) (Nishizawa et al. 2014), which may increase the density of active volcanoes on the arc when subducted

(See figure on next page.)

Fig. 1 a Regional tectonic map of the Ryukyu arc. Black color corresponds to areas above the sea level. Dark gray-shaded areas and light grayshaded areas indicate seafloors shallower than 1000 and 4000 m, respectively. Note that the Ryukyu arc is topographically divided into three segments by two across-arc bathymetric depressions (Tokara Channel in the north and Kerama Gap in the south). The dashed box shows the location of (b). $\mathbf{b}$ Seafloor topography map and layout of the MCS profiles (black lines). Reflection images along the thick black lines are presented in Fig. 3. Background colors represent seafloor depths in meter with contours every 500 m. Active volcanoes (Japan Meteorological Agency 2013; red triangles) are aligned on the back-arc side of the non-volcanic islands. Hydrothermal vent sites (red stars) are from Ishibashi et al. (2015). The magnitude and focal mechanism (black beach ball) of the 2015 earthquake are derived from the catalog by US Geological Survey (https://earthquake.usgs. gov/earthquakes/search/). This event demonstrates strike-slip faulting in this area (see text for discussion). $\mathbf{c}$ P wave velocity model of the northern Ryukyu arc along the RK02 profile (Arai et al. 2017b). It is noted that beneath the Tokara Channel the upper crustal layer (yellow color region with $P$ wave velocities of 5.0-6.0 km/s) becomes thinner than the adjacent arc/back-arc crust, indicating the arc crust has been extensionally stretched and thus led to the local subsidence at the location of the Tokara Channel (see text for discussion) 

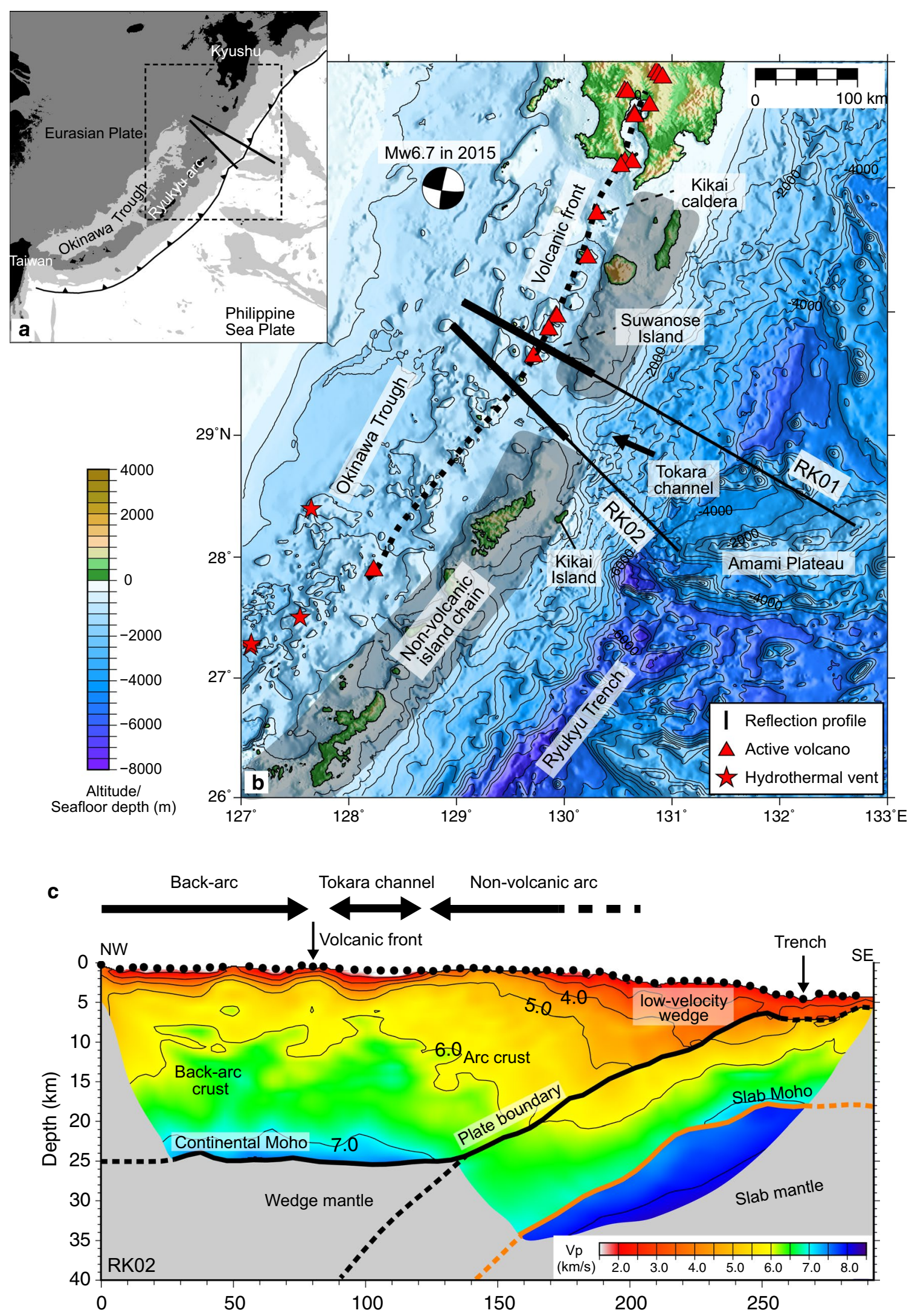
(Bourdon et al. 2003), whereas the Philippine Sea plate becomes more typical oceanic lithosphere to the south (Arai et al. 2016). The along-arc variation in subduction angle of the Philippine Sea slab may also play a role for generating this difference in volcanism (Nakamura et al. 2003).

During the last few decades, the volcanic system in the northern Ryukyu arc has been studied mainly using geological and geochemical methods: For example, volcanic rocks sampled from the active volcanoes in this region indicate the arc lavas are characterized as complex volcanic suites including basalt, andesite, dacite and rhyolite (Yokose et al. 2010). Another geochemical study shows that the current volcanic front has been active since approximately $2 \mathrm{Ma}$ and that the magma production there is enhanced by fluids dehydrated from the subducting slab (Shinjo et al. 2000). On the contrary to these advances, internal architectures of the volcanic arc based on geophysical approaches are poorly documented: Multiple seismic surveys have been carried out in the study area (Nash 1979; Iwasaki et al. 1990; Nakahigashi et al. 2004; Gungor et al. 2012; Nishizawa et al. 2017), but unfortunately none of them have discussed the volcanic structure in detail.

The Okinawa Trough is a depositional basin covered by thick sediments primarily provided from the westerly continental shelf (Narita et al. 1990). Paleomagnetic and geochronological studies suggest that the Ryukyu arc started to separate from the continent to form the back-arc basin at the late Miocene: The southern Ryukyu arc experienced a clockwise rotation since $10 \mathrm{Ma}$ while parallel rifting occurred for the central Ryukyu arc during this period (Miki 1995), which may have been followed by a counter-clockwise rotation of the northern Ryukyu arc since 1-2 Ma (Kodama et al. 1995). Seismic studies suggest that the Okinawa Trough is still at a stage of continental rifting prior to leading to seafloor spreading (Sibuet et al. 1998; Nakahigashi et al. 2004; Arai et al. 2017a). The global model of present-day plate motions predicts that the back-arc rifting along the northern Okinawa Trough occurs in the roughly east-west direction with a relatively slow rate of $22 \mathrm{~mm}$ /year (Argus et al. 2011), but former studies based on seismic fault mapping and shallow earthquakes suggest that the stress field there is more heterogeneous in space: Seismic reflection data reveal that the syn-rift normal fault system in the Okinawa Trough exhibits left-stepping en echelon structure, which probably reflects the along-trough variation in rifting rate and/or the oblique rifting direction with respect to the regional strikes of the arc and back-arc (Letouzey and Kimura 1985; Sibuet et al. 1998). The seismic studies also suggest that a well-developed axial rift zone as seen in the southern Okinawa Tough is missing in the northern Okinawa Trough and instead extensional deformation has occurred extensively, resulting in wide rift basins dominated by graben/half-graben structures (Nash 1979; Letouzey and Kimura 1985; Gungor et al. 2012). The focal mechanisms of local earthquakes also indicate complex tectonic stress regimes in the study area and suggest that the extensional stress field occurs not only in the arc-perpendicular direction but also in the arc-parallel direction, which can be explained by the outward migration of the arc (Kubo and Fukuyama 2003).

Although the Tokara Channel is a major topographic feature demarcating the Ryukyu arc, its formation process and relation to the arc/back-arc evolution are not fully understood: Previous studies suggest that the regional extension caused by the southward retreat of the Ryukyu Trench is the primary control on forming the across-arc topographic depression (Matsumoto et al. 1996). Based on the detailed bathymetric data, Kimura et al. (1993) and Matsumoto et al. (1996) also point out that the left-lateral strike-slip faulting has been occurring along the Tokara Channel, which may indicate that the Tokara Channel is responsible for accommodating across-arc displacements caused by the arc rotation associated with the back-arc rifting. On the other hand, the Tokara Channel does not correspond to the position with the maximum arc curvature and thus the relationship between the arc migration and the across-arc depressions is still unclear. Interestingly, the active uplifting of the arc crust has been happening at the Kikaijima Island located just south of the Tokara Channel (Ota et al. 1978), resulting in a contrasting tectonic movement in a small area (Fig. 1). Constraining the subsurface structure, there will be an important step for understanding how such complex tectonic processes work.

\section{MCS reflection data}

We acquired the MCS reflection data in 2015-2016 using R/V Kairei of Japan Agency for Marine-Earth Science and Technology (JAMSTEC). Two seismic transects with lengths of approximately $410 \mathrm{~km}$ (RK01) and $290 \mathrm{~km}$ (RK02) are extended from the Amami Plateau on the incoming Philippine Sea plate to the eastern part of back-arc basins in the northern Okinawa Trough (Fig. 1). The both lines cross the Ryukyu trench, the forearc slope and the active volcanic front. In the central part of the study area, the southern line of RK02 traverses the Tokara Channel while the northern line of RK01 runs through the non-volcanic island chain. Along these profiles, the shooting was conducted using Kairei's tuned air gun arrays with the maximum volume of 7800 cubic inch. The shooting interval was $50 \mathrm{~m}$. To record acoustic waves from the air gun shots, the 6-km-long hydrophone streamer with 444 channels was towed at $10 \mathrm{~m}$ depth 


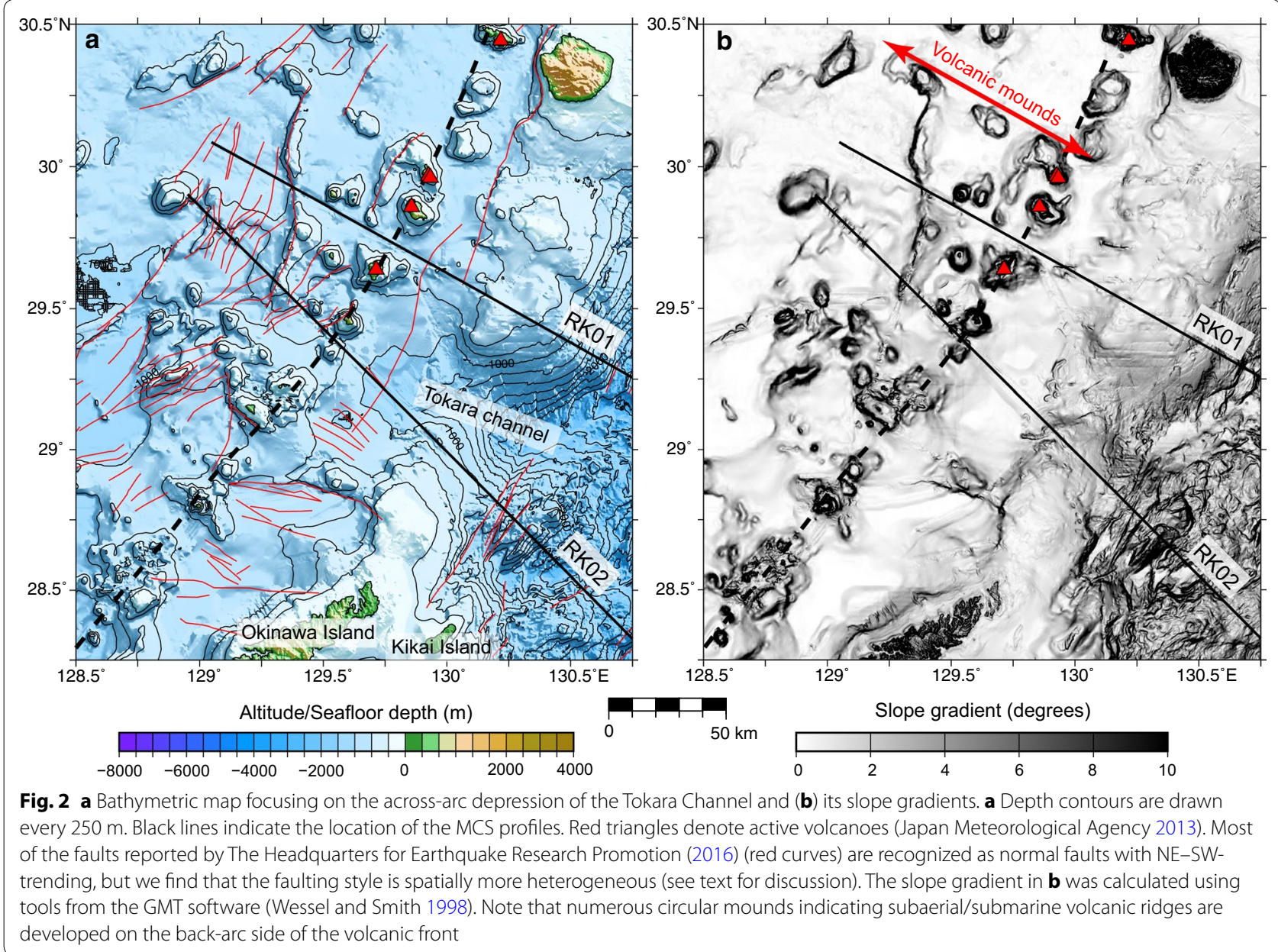

below the sea level. The positions of sources and receivers were determined using the global positioning system. The sampling rate for the recording was $2 \mathrm{~ms}$. Additional details concerning the data acquisition are provided in Arai et al. (2017b).

For analyzing the data, we followed the same procedure as Arai et al. (2017b): The obtained reflection data were processed using a standard scheme which includes trace editing, band-pass filtering, datum correction, amplitude compensation for geometrical spreading, predictive deconvolution, velocity analysis, normal moveout correction, mute, common midpoint stacking (6.25-m interval) and time migration.

\section{Results}

The seismic reflection data reveal structural details of the northern Ryukyu arc and the northern Okinawa Trough. The overall images are presented in Fig. 3, which highlight the large-scale undulation of the acoustic basement. Since we find a variety of structural features reflecting complex tectonic and magmatic events, we divide the study area into three domains and describe them separately in the following sections, namely the Tokara Channel ("Tokara Channel" and "Arc segmentation" sections, and Fig. 4), the volcanic front ("Volcanic front" and "Active magmatic intrusions around the volcanic front" sections, and Figs. 5 and 6) and the back-arc basins ("Back-arc basins" and "Fault development and rifting style in the northern Okinawa Trough" sections, and Figs. 7 and 8).

\section{Tokara Channel}

One of the most important findings from our reflection data is the deep sedimentary basin beneath the Tokara Channel (Fig. 4): The acoustic basement marked by highamplitude reflections forms a $\sim 30$-km-wide bowl-shaped basin with the maximum depth of $\sim 2 \mathrm{~s}$ two-way travel time ( $\sim 3 \mathrm{~km}$ deep below the seafloor) relative to the adjacent arc segment. It should be noted that since the seismic profile is oblique to the strike of the Tokara Channel, the actual width of the basin in the along-arc direction is much smaller. The basin is filled with subhorizontal 
reflectors, and the velocity model supports that they represent low-velocity sedimentary units deposited on the arc crust (Fig. 1c). Although the deformation pattern within the basin is not obvious, the sedimentary layers clearly show a downward convex geometry and step-like features across the layers at some locations (Fig. 4). Correspondingly, the acoustic basement also exhibits multiple steps in the southeastern part of the basin, but the basement itself becomes ambiguous in the northwestern part (Fig. 4).

\section{Volcanic front}

In the reflection images around the volcanic front, we find numerous transparent bodies within the shallow sediments and the crust (Figs. 5 and 6): They are characterized by a narrow, vertically elongated pipe-like shape with low amplitudes of seismic reflections. These bodies are typically $\sim 1 \mathrm{~km}$ wide and tend to become slighter wider with increasing depth. Based on these features and the proximity to active volcanoes, we interpret them to be volcanic intrusions caused by magmatic upwelling. The tubular shapes are commonly imaged as a transparent region compared to the surrounding sedimentary layers or crust. The transparency suggests that they consist of materials with high scattering, such as sheeted dikes, and represent a conduit from a deep magma reservoir. In the reflection image of the RK02 profile, intrusive bodies penetrate the shallow lithosphere and reach the seafloor to form volcanic mounds (Fig. 6). Correspondingly, the seafloor bathymetric data show that these ridges are densely distributed around active volcanoes (Fig. 2). In addition to the obvious intrusions forming the volcanic ridges, we detect several more "blind" intrusions buried within the sedimentary layers where the seafloor is paved by rapid sedimentation and their existence cannot be confirmed only by the bathymetric data (RK01 profile

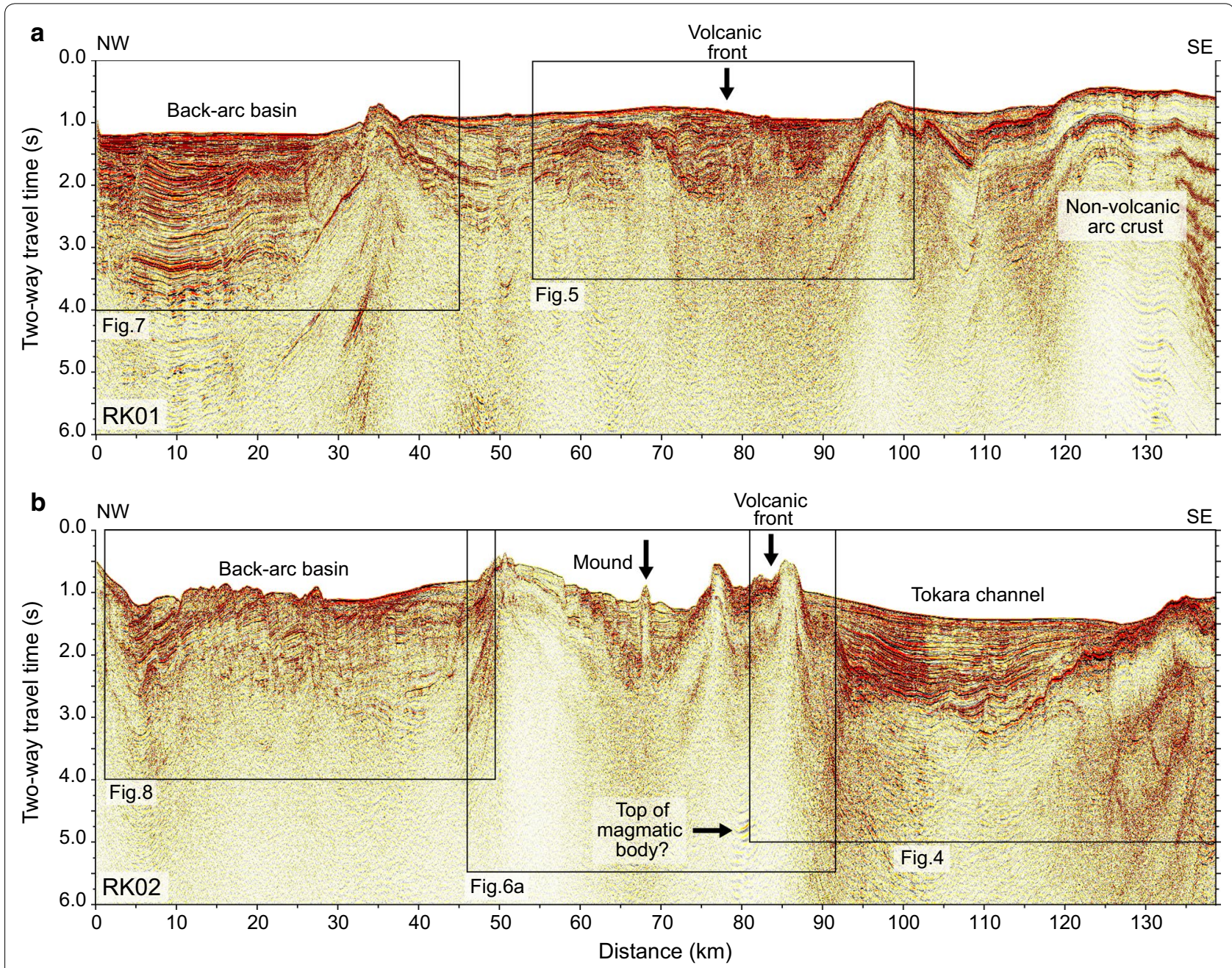

Fig. 3 Seismic reflection images across the northern Ryukyu arc. a RK01 profile. b RK02 profile. The locations of the profiles are shown in Fig. $1 \mathrm{~b}$ (thick black lines). Black boxes indicate the locations of the close-up images in Figs. 4, 5, 6, 7 and 8 
in Fig. 5). Another interesting feature is that some of the intrusive bodies are capped by a convex reflector, indicating a sedimentary layer pushed up by the upwelling flow (blue arrows in Fig. 5). It is also worth noting that dipping reflective patches are often observed at the roots of the transparent tubes (Fig. 6).

Seafloor magnetic data are often used as supporting information on magmatic intrusions. We checked the

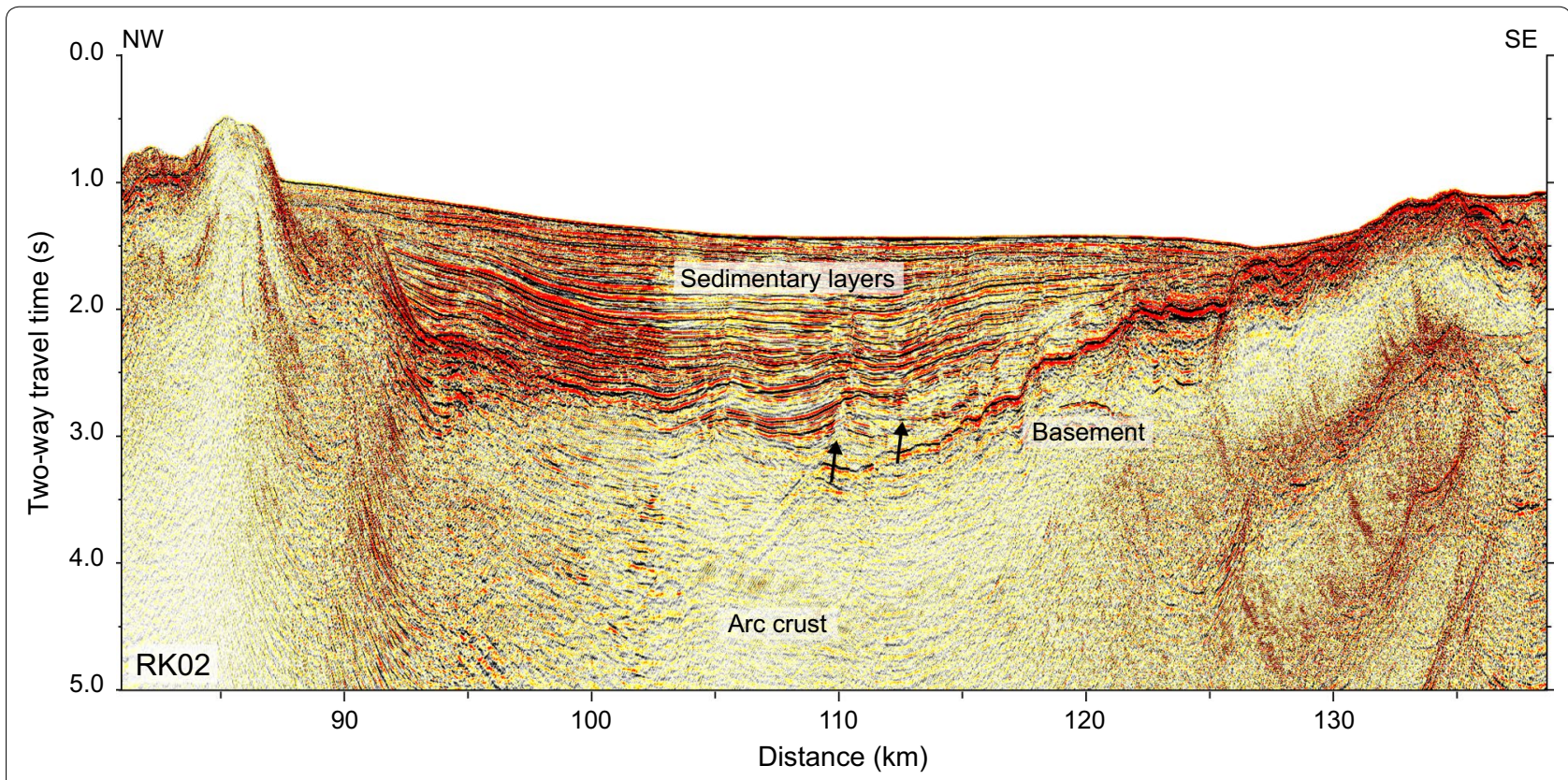

Fig. 4 Seismic reflection image of the RK02 profile focusing on the Tokara Channel. The acoustic basement marked by high-amplitude reflections forms a 30-km-wide bowl-shaped basin with the maximum depth of $\sim 2 \mathrm{~s}$ two-way travel time (equivalent to $\sim 3 \mathrm{~km}$ ) relative to the adjacent nonvolcanic arc segment. The basin is filled with subhorizontal reflectors indicative of sedimentary units deposited on the arc crust. The sedimentary layers show a downward convex geometry and step-like features across the layers as indicated by black arrows. The acoustic basement also exhibits multiple steps in the southeastern part of the basin

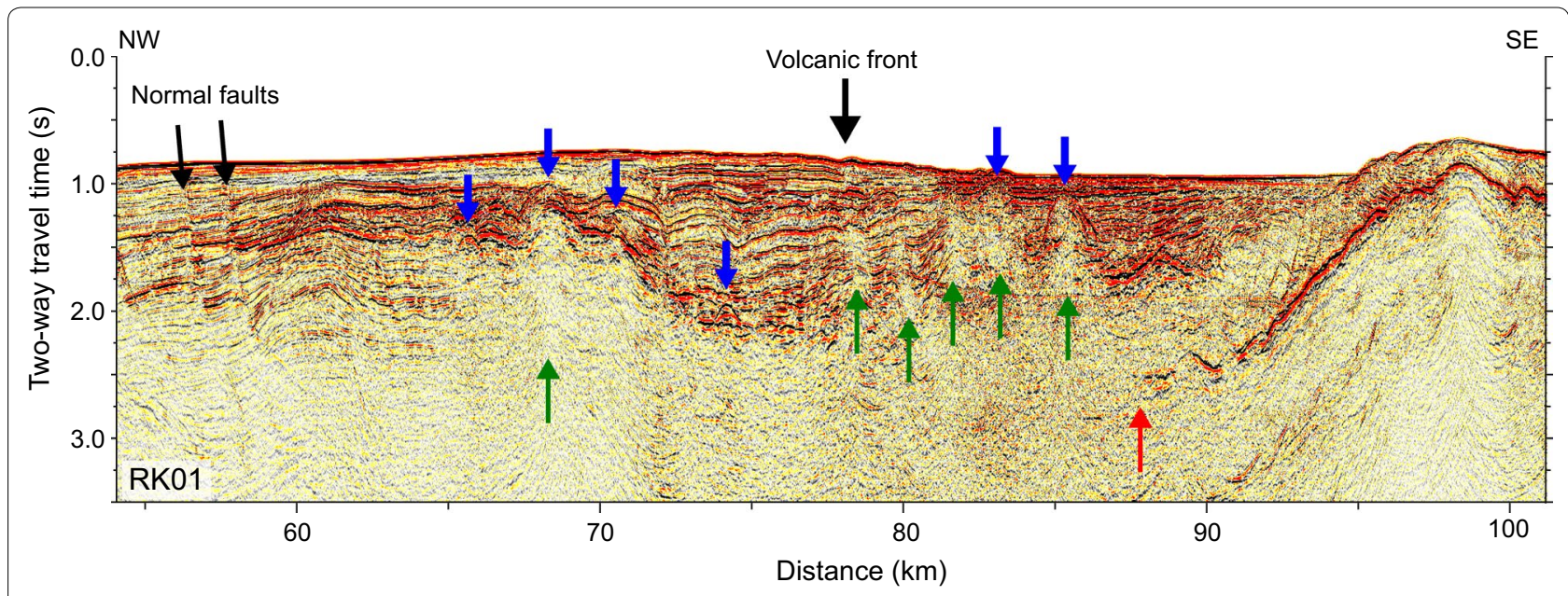

Fig. 5 Seismic reflection image showing "buried" magmatic intrusions along the RK01 profile. This image highlights tubular transparent bodies indicating volcanic conduits (shown by green arrows). Upwardly convex reflectors are interpreted to be sedimentary layers pushed up by the upwelling flow (blue arrows). The sudden disappearance of the high-amplitude reflector (acoustic basement) which is coincident with the distribution of the volcanic conduits (red arrow) also supports that the arc crust is highly disturbed by magmatic intrusions. On the western part of the basin, normal faults displacing the sedimentary layers are observed (black arrows) 


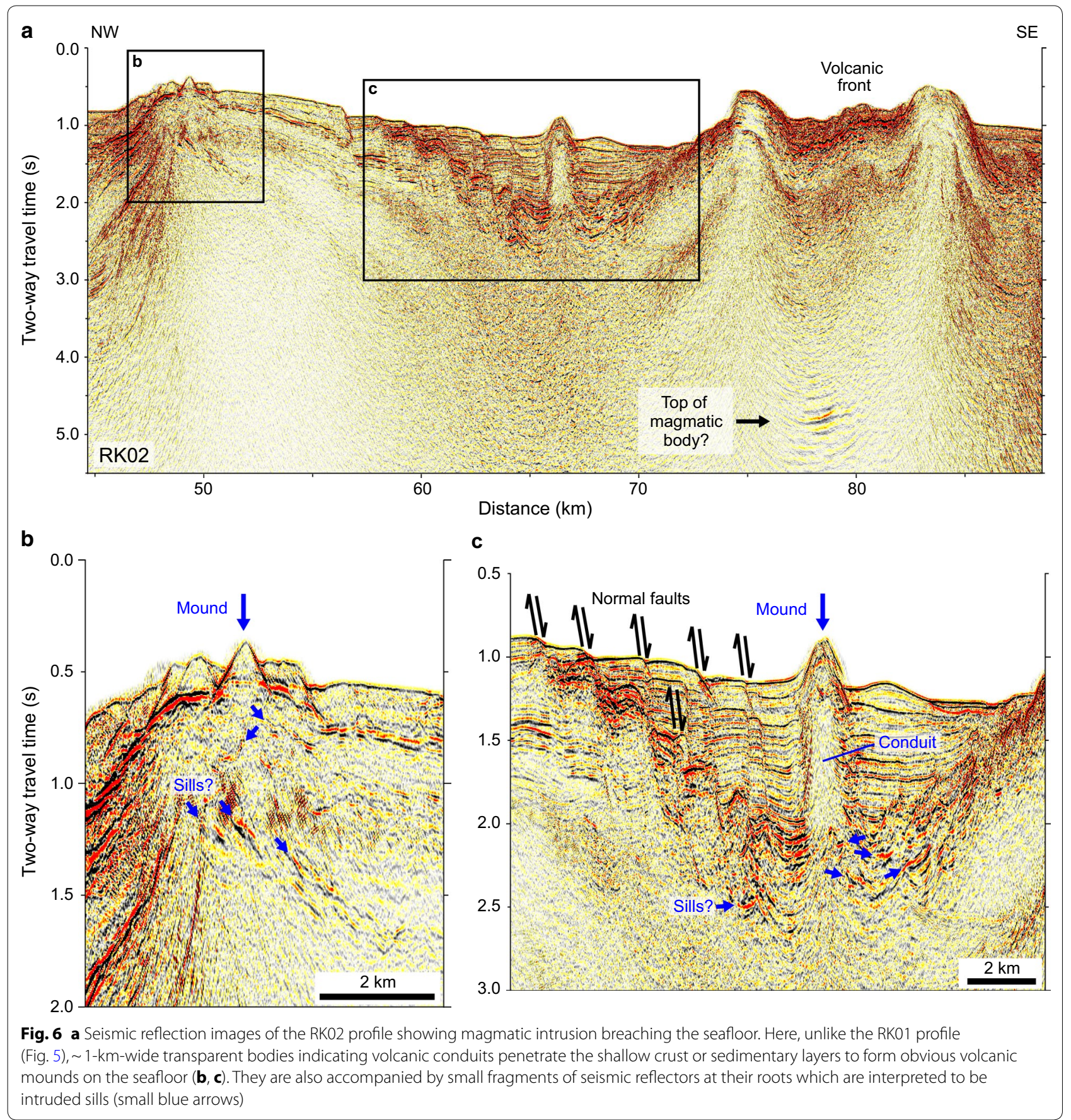

magnetic data recorded during the seismic experiments by using the shipboard magnetometer. However, no positive signals corresponding to the intrusions were found. This is probably because the magnetic data can be contaminated by the ship's magnetization effect. In addition, the magmatic intrusions we imaged by the reflection data are too small $(<1 \mathrm{~km}$ wide and $<100 \mathrm{~m}$ tall; Fig. 6$)$ to be detected and thus more close-in observations using deep-towed magnetometers or submersibles are necessary.

In the reflection image of RK02, a distinct deep reflector is imaged at the two-way travel time of $\sim 5 \mathrm{~s}$, which is equivalent to $\sim 9 \mathrm{~km}$ depth below the seafloor (Fig. 6). Since its horizontal location corresponds to the volcanic front and the appearance is similar to a melt lens reflector observed in volcanic regions (Arai et al. 2017a), the 

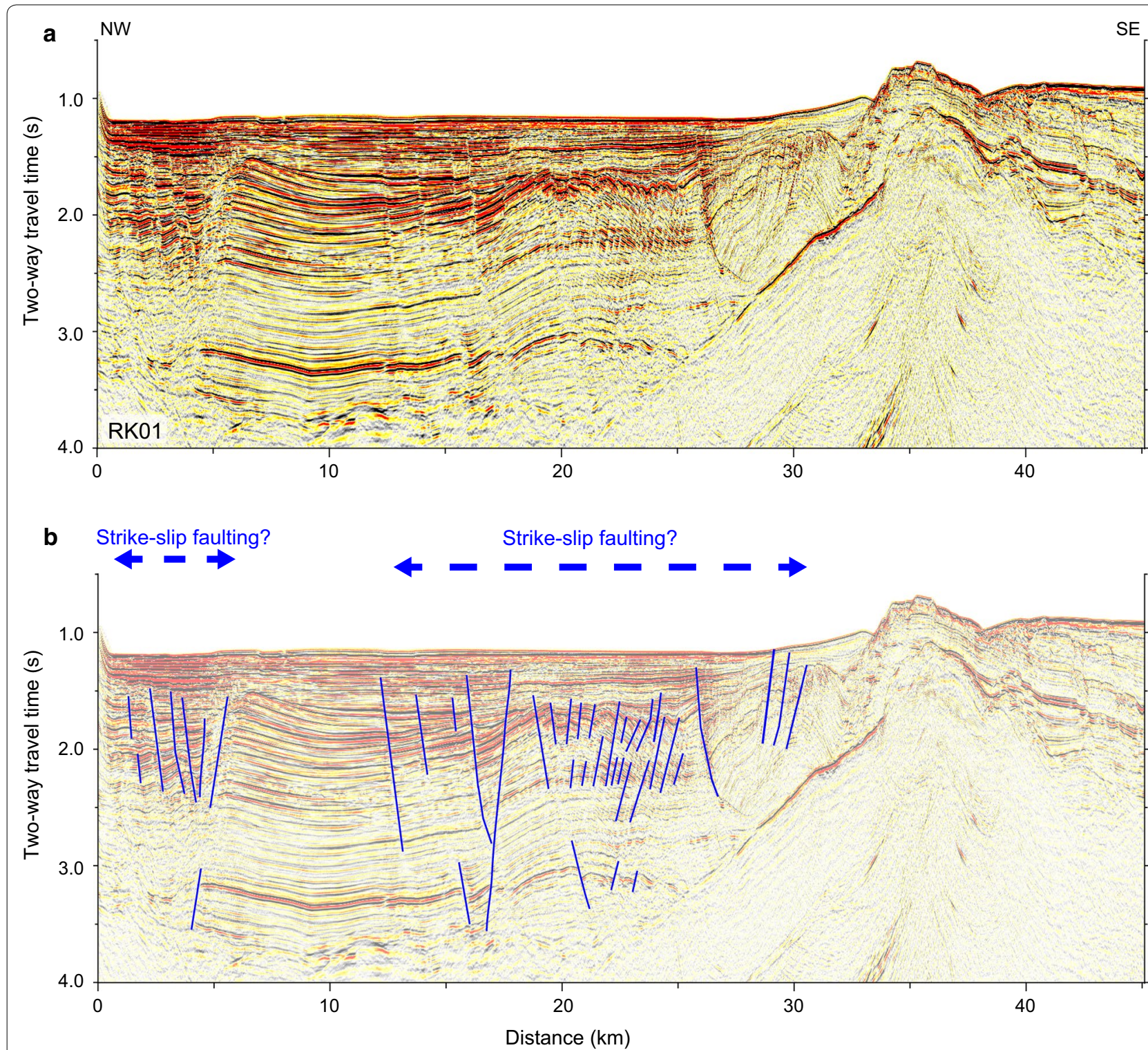

Fig. 7 a Seismic reflection images of the back-arc basin along the RK01 profile and $\mathbf{b}$ its interpretation. Blue lines in $\mathbf{b}$ indicate interpreted displacements. Despite the almost flat seafloor bathymetry of the basin, fault displacements across the sedimentary layers densely occur at many locations. Most of them crosscut each other and thus are interpreted to represent a "flower structure" probably caused by strike-slip movements

reflector appears to represent a magmatic feature. However, caution is needed when interpreting its depth: The estimated depth is significantly greater than that found in the southern Okinawa Trough (i.e., $4 \mathrm{~km}$ depth below the seafloor) (Arai et al. 2017a). In addition, the P wave velocity model does not show any low-velocity anomaly indicative of a magmatic body at this location (Fig. 1c). Hence, this reflection phase may not come from the structure just below the seismic line but be a sideswipe from an out-of-line volcano: The seismic profile of RK02 runs through between the obvious volcanic ridges and the horizontal distances to the volcanic ridges nearby are 6-10 km (Fig. 2). If the seismic reflections we observed were derived from one of these volcanoes, the reflector is likely to be located at a more typical depth for a magma chamber.

\section{Back-arc basins}

In the back-arc basins $>30 \mathrm{~km}$ away from the volcanic front, the aforementioned magmatic structures disappear, and alternatively rifting-related fault system becomes more obvious (Figs. 7 and 8). Here the rift 


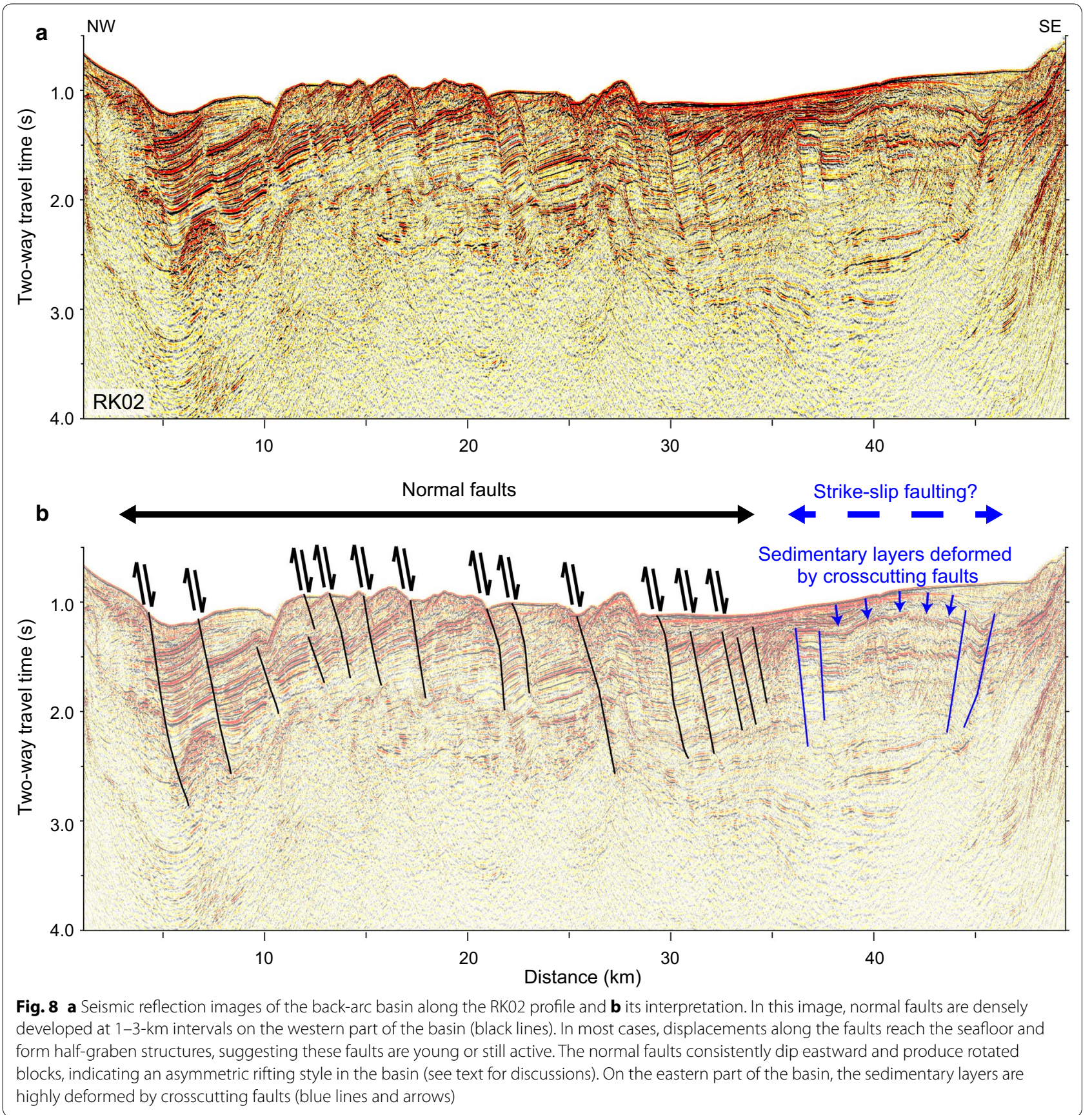

basins are characterized by deep sediments in which high-angle faults are developed very densely. On the northern profile of $\mathrm{RK} 01$, the sedimentary layers are crosscut by multiple faults dipping to the east and the west, but vertical displacement at the seafloor and along the faults is not significant (Fig. 7). These are typical features of a so-called flower structure caused by strike-slip faulting (Woodcock and Fischer 1986). On the other hand, despite the short distance from the RK01 profile, the reflection image of the RK02 profile is remarkably different from that of the RK01 profile, which is dominated by a series of eastward dipping normal faults forming the half-graben structures on the rotated blocks (Fig. 8). Such a rapid transition in faulting style shows that each fault is highly segmented, probably owing to the back-arc extension occurring obliquely to the regional trend of the Okinawa Trough. It is also noted that most of the normal faults tectonize the thick sedimentary layers and reach 
the seafloor, suggesting that these faults are young or still active (Fig. 8).

\section{Discussion}

\section{Arc segmentation}

The Tokara Channel is a major segment boundary across the Ryukyu arc, but its deep structure and role in arc evolution have not been examined in detail. Although our seismic line of RK02 profile crosses the westernmost part of the valley, the seismic image reveals the deep basin structure (up to $3 \mathrm{~km}$ deep) there (Fig. 4). Based on the bathymetric data, Matsumoto et al. (1996) suggest that left-lateral strike-slip faulting predominantly occurs along this valley. Generally, such a deep basin can be produced by strike-slip faulting (i.e., pull-apart basin). However, the strike-slip faulting alone is unlikely to produce the structure of the Tokara Channel: The P wave velocity model shows that beneath the Tokara Channel the upper crustal layer beneath the sedimentary units (yellow color region with $P$ wave velocities of $5.0-6.0 \mathrm{~km} / \mathrm{s}$ in Fig. 1c; Arai et al. 2017b) becomes significantly thinner than the surrounding arc/back-arc crust. This thinned upper crust implies that the arc crust itself has been extensionally stretched at the location of the Tokara Channel.

Although the formation mechanism of the acrossarc topographic depression is not fully understood, the aforementioned structural constraints may require an extensional process acting on the arc itself. The Ryukyu arc has a curved geometry along the subduction trench, and thus, the outward arc migration associated with the back-arc rifting increases the circumference of the arc, giving rise to an arc-parallel extensional stress field in the forearc region (ten Veen and Kleinspehn 2002). As evidence for this, studies using local seismicity demonstrate the arc-parallel extensional stress regime in the forearc region of the northern Ryukyu arc (Kubo and Fukuyama 2003; Otsubo et al. 2008). It is therefore suggested that although strike-slip motion may have been ongoing along the Tokara Channel to accommodate across-arc lateral displacements, the arc-parallel stretching derived from the seaward arc migration is a primary control on the tectonic process on the Tokara Channel. If the arc-parallel extensional stress is currently dominant along the Tokara Channel, normal faulting may be expected to develop within the basin. Correspondingly, the acoustic basement exhibits multiple steps indicative of an extensional process. Although the infill sediments look less deformed, the sedimentary layers show a downward convex geometry and step-like features across the layers at some locations, same as the shape of the basin (Fig. 4). We suggest that the lack of clear normal faults in the reflection image is precisely because our seismic profile is oriented almost orthogonal to the arc strike (i.e., extensional direction) and is thus sub-parallel to the strike of normal faults. Another potential cause for the lack is that there may have been a time difference in formation of the basin and sediments infilling. Matsumoto et al. (2009) report an across-arc active normal fault in the southern Ryukyu arc, which may have been caused by such arc-parallel stretching.

One may argue that other factors may contribute to forming such a local subsidence in the arc/forearc region. A well-known mechanism for a forearc subsidence is subduction erosion (e.g., von Huene and Scholl 1991). Okamura et al. (2017) show that while most parts of the Ryukyu forearc have experienced a significant subsidence caused by an erosional process of the subducting ridges, the northern Ryukyu arc exhibits landward dipping sedimentary units bounded by numerous thrust faults indicating the presence of an actively growing accretionary prism. Along the RK02 profile, the frontal wedge of the overriding plate seems to have been deformed by the subduction of the thick oceanic plateau (Arai et al. 2017b). However, the subduction of these buoyant ridges is unlikely responsible for forming the Tokara Channel because the plateau is several times wider than the across-arc valley. Furthermore, the subduction of the buoyant plateau is currently enhancing the rapid uplift of the overriding forearc crust as exemplified at the Kikaijima Island rather than causing a subsidence (Kato 1997).

\section{Fault development and rifting style in the northern Okinawa Trough}

The northern Okinawa Trough is thought to have experienced different episodes of back-arc extension from the southern part (Miki 1995), which, together with the southwestward increase in rifting rate (Argus et al. 2011), produced a clear along-trough variation in seafloor topography and rifting style: As demonstrated by seismic studies of Arai et al. (2017a) and their predecessors, the southern Okinawa Trough hosts a relatively narrow and deep rift basin in which normal faults are densely developed in a symmetric manner across the rift axis. Although our seismic reflection data sampled only the eastern part of the northern Okinawa Trough, it is likely that the rifting-derived faults are being actively developed at multiple locations and thus that the northern Okinawa Trough is characterized as a diffuse rift basin where the crustal deformation is not localized to the rift axis but widely distributed across the entire basin (Figs. 7 and 8).

Our seismic data confirm that, unlike the southern Okinawa Trough, the faulting style in the northern Okinawa Trough is significantly asymmetric (e.g., eastward dipping normal faults shown in Fig. 8). It is generally known that such deformation style and faulting pattern 
in a rift basin vary depending on several parameters, such as the strength and thermal structure of the plate and the extension rate (e.g., Ruppel 1995). Gungor et al. (2012) argue that the subduction of the thick Amami Plateau at the northern Ryukyu Trench plays a primary role for the diffuse rifting in the northern Okinawa Trough by producing a local disturbance in speed of the trench rollback and the resultant back-arc rifting rate. As another effect, we here point out that the lithosphere consisting of the northern Ryukyu arc and the northern Okinawa Trough is probably hotter and weaker than typical continental lithospheres due to the active upwelling of magma from the subducting slab (Wang et al. 2008). Within such a hot and weak plate, extensional strain tends to be delocalized and a broad deformation zone is formed more easily (Buck et al. 1999). We also note that the rifting rate decreases as it goes northeastward along the Okinawa Trough and the current extension is thought to occur at a slow rate of $22 \mathrm{~mm} /$ year around the study area (Argus et al. 2011). If this slow rate has been persistent over the rifting history, it also contributes to forming a diffuse basin (Huismans and Beaumont 2003).

Another important structural feature in the northern Okinawa Trough is spatial variation in faulting pattern: Previous studies of fault mapping report no strike-slip faults in this area (The Headquarters for Earthquake Research Promotion 2016), but our reflection images clearly show flower structures indicative of the strikeslip faults at several locations (Fig. 8). The existence of strike-slip faults is also supported by focal mechanisms of local seismicity (Otsubo et al. 2008). Terakawa and Matsu'ura (2010) indicate a complicated pattern of tectonic stress in the northern Okinawa Trough including rapid changes from normal faulting to strike-slip faulting at crustal depths. As more definitive evidence, a large right-lateral strike-slip earthquake (Mw6.7) occurred in 2015 northwest of our seismic profiles (Fig. 1b). This earthquake was a shallow crustal event and led to generating a small tsunami. Generally, large-scale strike-slip faulting is a common phenomenon in extensional rift zones, such as the Dead Sea Rift (ten Brink et al. 1993), and is thought to play an essential role in accommodating the obliquity between the rifting direction and the rift axes. In the case of northern Ryukyu, the rifting rate varies in the along-trough direction (Argus et al. 2011) and the rifting direction is oblique to the regional strikes of the arc and back-arc (Letouzey and Kimura 1985; Sibuet et al. 1998). In addition, the arc rotation is probably happening around the site where the buoyant Amami Plateau is colliding with the overriding plate at the trench since the trench rollback is locally impeded by the collision (Wallace et al. 2005). These tectonic factors may be responsible for producing an extremely complicated stress field and resulting in complex faulting styles as we observed. Unfortunately, strike-slip faults are usually difficult to know the orientation and spatial continuity from seafloor bathymetry alone since they do not necessarily produce a vertical displacement at the seafloor. The high sedimentation rate in the northern Ryukyu region also makes it difficult to trace. In order to fully understand the fault distribution, more extensive investigations incorporating seismic imaging and seismicity observation will be necessary.

\section{Active magmatic intrusions around the volcanic front}

Another prominent finding in this study is seismically transparent bodies around the volcanic front indicating volcanic conduits (Figs. 5 and 6). Since some of the intrusions are completely overlain by thick sediments (RK01 profile in Fig. 5), the number of volcanic intrusions must be significantly greater than that estimated from their bathymetric expression. Interestingly, the volcanic conduits are widely distributed from the volcanic front to 20-30 km west of the volcanic front, whereas such features are not observed in the easterly non-volcanic arc and the forearc region (Fig. 2). The implication from this observation is that magmatic intrusions are enhanced by back-arc rifting: At some locations, steeply dipping normal faults are imaged in the proximity to these volcanic conduits (Fig. 6c). They have been developed in the process of arc/back-arc rifting and may facilitate magmatic upwelling by providing its pathways at crustal depths. The widespread magmatic conduits may suggest that the arc volcanism has several off-axis outlets discharging volcanic products: In this case, some portions of the upwelling magma need to bifurcate at crustal levels and migrate laterally toward the back-arc side. Such horizontal transportation of magma may be possible where the regional stress field is favorable for forming extensive fissure system as reported in similar arc volcanic regions (Ishizuka et al. 2014). Another possible scenario to explain the widespread volcanic conduits is that the arc volcanoes themselves have been migrating trenchward over time. The location of the volcanic front is known to be fluctuated on a geological time scale (e.g., Yamaji 2003), and indeed the volcanic front along the Ryukyu arc is thought to have migrated eastward in accordance with the eastward retreat of the Ryukyu Trench during 2-4 Ma (Shinjo et al. 2000).

Magmatic intrusions observed as transparent bodies in the reflection images seem to be a common phenomenon in continental rift zones as similar structures are reported in Gulf of California (Lizarralde et al. 2011), south of Australia (Jackson et al. 2013) and off Norway (Planke et al. 2005; Iyer et al. 2017). Intrusive bodies are also found in the southern Okinawa Trough (Arai et al. 2017a). 
However, the detail architectures are slightly different from each other. For example, in the southern Okinawa Trough a magmatic intrusion occurs just beneath the rift axis and the basin-fill sedimentary layers dip toward the rift axis on the both sides of the axis, suggesting that the on-axis intrusion was caused by "passive" upwelling of magma (Arai et al. 2017a). It is also suggested in the southern Okinawa Trough that the intrusion is linearly continuous along the rift axis and thus forms a thin "wall" consisting of plutonic materials. On the other hand, intrusive structures in the northern Ryukyu arc have a circular cone shape and do not show inward-dipping sedimentary layers. It is therefore indicated that they were produced by "active" upwelling (Fig. 6c). This latitudinal variation is consistent with the density of active volcanoes. We suggest that the magmatic intrusions in the southern Okinawa Trough are a direct consequence of the back-arc rifting while the volcanism to the north is robustly supported by abundant magmatic supply from the subducting slab (Shinjo et al. 2000).

Another important feature we found is dipping reflective patches at the bottoms of the volcanic conduits, which are obviously isolated from reflections indicating the sediments and basement. Although there seems to be no definitive criteria for their interpretations, these features are often regarded as magmatic sills that may be able to provide sufficient heat for hydrothermal venting on the seafloor (Iyer et al. 2017; Canales et al. 2017). Another possibility is that the dipping reflectors represent channels for hydrothermal fluid flows (Tsuji et al. 2012). Hydrothermal vents have not been reported around the northern Ryukyu volcanic arc to date despite many having been found in the central and southern Okinawa Trough. Our seismic data suggest that although many of the magmatic intrusions are buried and thus cooled by thick sedimentary materials, other intrusions breaching the seafloor may have a potential to host hydrothermal vents on the seafloor. In order for hydrothermal vents to be active, normal faults need to be developed nearby to facilitate seawater infiltration down to a subsurface heat source at depth (Tsuji et al. 2012). In the case of the northern Ryukyu, syn-rift normal faults in the proximity of volcanic intrusions may contribute to this process (Fig. 6c).

\section{Conclusions}

Based on the MCS reflection images, we present structural constraints on the arc segments boundary, magmatic intrusions and faulting patterns in the northern Ryukyu arc. The major findings are summarized as follows:
1. Beneath the across-arc bathymetric depression of the Tokara Channel, there exists a 3-km-deep sedimentary basin atop the arc crust, which, together with the thinned upper crust, suggests that the arc-parallel extension derived from the outward migration of the Ryukyu arc has produced this valley.

2. Numerous volcanic conduits are observed within the sedimentary basins and shallow crust around the volcanic front. They are characterized as a $\sim 1-\mathrm{km}$-wide tube-like shape, and their abundance shows that volcanic intrusions are a ubiquitous feature in the northern Ryukyu arc. The spatial distribution of the conduits may suggest that the arc volcanism has multiple active outlets for discharging volcanic products and/ or that the location of the volcanic front has been migrating trenchward over time. We also find some of the conduits are accompanied by intruded sills at their bottoms, implying the existence of a potential heat source driving hydrothermal circulations.

3. The northern Okinawa Trough forms diffuse basins on which thick sedimentary units pile up. Within the basins, numerous high-angle faults are densely developed in an asymmetric manner. The faulting patterns rapidly change from normal faults to strike-slip faults, suggesting complex stress regimes associated with arc/back-arc rifting.

\section{Abbreviations}

MCS: multichannel seismic; JAMSTEC: Japan Agency for Marine-Earth Science and Technology; RN: research vessel; GMT: Generic Mapping Tools.

\section{Authors' contributions}

RA participated in the data acquisition cruise, led interpreting the MCS reflection data and wrote the manuscript. SK supervised the data acquisition and processing and participated in interpretation. TT designed and participated in the data acquisition cruise as a chief scientist. SM and YK organized the data acquisition cruise and participated in interpretation. All authors read and approved the final manuscript.

\section{Author details}

${ }^{1}$ Research and Development Center for Earthquake and Tsunami, Japan Agency for Marine-Earth Science and Technology, 3173-25 Showa-machi Kanazawa-ku, Yokohama, Kanagawa 236-0001, Japan. ${ }^{2}$ Institute of Education, Research and Regional Cooperation for Crisis Management Shikoku, Kagawa University, 1-1 Saiwai-cho, Takamatsu, Kagawa 760-8521, Japan.

\section{Acknowledgements \\ We gratefully appreciate the captain, crew and technicians onboard the R/V Kairei for their dedicated work for obtaining high-quality MCS reflection data during the KR15-21 cruise. The seismic survey was conducted as part of "Research project for compound disaster mitigation on the great earthquakes and tsunamis around the Nankai Trough region" funded by the Ministry of Education, Culture, Sports, Science and Technology, Japan. Some figures were drawn with Generic Mapping Tools (GMT) (Wessel and Smith 1998). The seismic data used in this study are available from the JAMSTEC database site (https://www.jamstec.go.jp/jamstec-e/IFREE_center/index-e.html).}

Competing interests

The authors declare that they have no competing interests. 
Consent for publication

Not applicable.

\section{Ethics approval and consent to participate}

Not applicable.

\section{Publisher's Note}

Springer Nature remains neutral with regard to jurisdictional claims in published maps and institutional affiliations.

Received: 7 December 2017 Accepted: 4 April 2018

Published online: 17 April 2018

\section{References}

Arai R, Takahashi T, Kodaira S, Kaiho Y, Nakanishi A, Fujie G, Nakamura Y, Yamamoto Y, Ishihara Y, Miura S, Kaneda Y (2016) Structure of the tsunamigenic plate boundary and low-frequency earthquakes in the southern Ryukyu Trench. Nat Com 7:12255. https://doi.org/10.1038/ncomms12255

Arai R, Kodaira S, Kaiho Y, Takahashi T, Miura S, Kaneda Y (2017a) Crustal structure of the southern Okinawa Trough: symmetrical rifting, submarine volcano, and potential mantle accretion in the continental back-arc basin. J Geophys Res Solid Earth 122:622-641. https://doi. org/10.1002/2016JB013448

Arai R, Kodaira S, Yamada T, Takahashi T, Miura S, Kaneda Y, Nishizawa A, Oikawa M (2017b) Subduction of thick oceanic plateau and high-angle normalfault earthquakes intersecting the slab. Geophys Res Lett 44:6109-6115. https://doi.org/10.1002/2017GL073789

Argus DF, Gordon RG, DeMets C (2011) Geologically current motion of 56 plates relative to the no-net-rotation reference frame. Geochem Geophys Geosyst 12:Q11001. https://doi.org/10.1029/2011GC003751

Bourdon E, Eissen J-P, Gutscher M-A, Monzier M, Hall ML, Cotton J (2003) Magmatic response to early aseismic ridge subduction: the Ecuadorian margin case (South America). Earth Planet Sci Lett 205:123-138

Buck WR, Lavier LL, Poliakov ANB (1999) How to make a rift wide. Philos Trans R Soc A 357:671-693

Canales JP, Dunn RA, Arai R, Sohn RA (2017) Seismic imaging of magma sills beneath an ultramafic-hosted hydrothermal system. Geology 45:451455. https://doi.org/10.1130/G38795.1

Gungor A, Lee GH, Kim H-J, Han H-C, Kang M-H, Kim J, Sunwoo D (2012) Structural characteristics of the northern Okinawa Trough and adjacent areas from regional seismic reflection data: geologic and tectonic implications. Tectonophysics 522-523:198-207

Huismans RS, Beaumont C (2003) Symmetric and asymmetric lithospheric extension: relative effects of frictional-plastic and viscous strain softening. J Geophys Res 108:2496. https://doi.org/10.1029/2002JB002026

Ishibashi J, Ikegami F, Tsuji T, Urabe T (2015) Hydrothermal activity in the Okinawa Trough back-arc basin: Geological background and hydrothermal mineralization. In: Ishibashi J et al (ed) Subseafloor biosphere linked to hydrothermal systems:TAIGA concept, pp 337-359. https://doi. org/10.1007/978-4-431-54865-2_27

Ishizuka O, Geshi N, Kawanabe Y, Ogitsu I, Taylor RN, Tuzino T, Sakamoto I, Arai K, Nakano S (2014) Long-distance magma transport from arc volcanoes inferred from the submarine eruptive fissures offshore Izu-Oshima volcano, Izu-Bonin arc. J Volcanol Geother Res 285:1-17

Iwasaki T, Hirata N, Kanazawa T, Melles J, Suyehiro K, Urabe T, Moller L, Makris J, Shimamura H (1990) Crustal and upper mantle structure in the Ryukyu Island Arc deduced from deep seismic sounding. Geophys J Int 102:631-651

Iyer K, Schmid DW, Planke S, Millett J (2017) Modelling hydrothermal venting in volcanic sedimentary basins: impact on hydrocarbon maturation and paleoclimate. Earth Planet Sci Lett 467:30-42

Jackson CA-L, Schofield N, Golenkov B (2013) Geometry and controls on the development of igneous sill-related forced folds: a 2-D seismic reflection case study from offshore southern Australia. Geol Soc Am Bul 125:1874-1890. https://doi.org/10.1130/B30833.1

Japan Meteorological Agency (2013) National catalogue of the active volcanoes in Japan, 4th edn. Japan Meteorological Agency, Tokyo. http://
www.data.jma.go.jp/svd/vois/data/tokyo/STOCK/souran_eng/menu.htm. Accessed 1 Dec 2017

Kato Y (1997) The tectonic landform in the continental slope deformed by the collision of the Amami Plateau. J Geogr 106:567-579 (in Japanese with English abstract)

Kimura M, Matsumoto T, Nakamura T, Nishida S, Ono T, Aoki M (1993) Diving survey in the Tokara Strait: tectonic development of the eastern margin of the northern Okinawa Trough. Proc JAMSTEC Symp Deep Sea Res 9:283-307 (in Japanese with English abstract)

Kobayashi K (1985) Sea of Japan and Okinawa Trough. In: Nairn AEM, Stehli, FG, Uyeda S (eds) The ocean basins and margins, vol 7A. The Pacific Ocean. Plenum Publishing Corporation New York, pp 419-458

Kodama K, Tashiro H, Takeuchi T (1995) Quaternary counterclockwise rotation of south Kyushu, southwest Japan. Geology 23:823-826

Konishi K (1965) Geotectonic framework of the Ryukyu Islands (Nansei-shoto). J Geol Soc Jpn 71:437-457 (in Japanese with English abstract)

Kubo A, Fukuyama E (2003) Stress field along the Ryukyu Arc and the Okinawa Trough inferred from moment tensors of shallow earthquakes. Earth Planet Sci Lett 210:305-316

Letouzey J, Kimura M (1985) The Okinawa Trough genesis, structure and evolution of a back-arc basin developed in a continent. Mar Pet Geol 2:111-130

Lizarralde D, Soule SA, Seewald JS, Proskurowski G (2011) Carbon release by off-axis magmatism in a young sedimented spreading centre. Nat Geosci 4:50-54. https://doi.org/10.1038/NGEO1006

Machida H, Arai F (1978) Akahoya ash-a Holocene widespread tephra erupted from the Kikai Caldera, South Kyushu, Japan. Quat Res 17:143163 (in Japanese with English abstract)

Matsumoto T, Kimura M, Nakamura A, Aoki M (1996) Detailed bathymetric features of Tokara and Kerama Gaps in the Ryukyu Arc. J Geogr 105:286-296 (in Japanese with English abstract)

Matsumoto T, Shinjo R, Nakamura M, Kimura M, Ono T (2009) Submarine active normal faults completely crossing the southwest Ryukyu Arc. Tectonophysics 466:289-299

Miki M (1995) Two-phase opening model for the Okinawa Trough inferred from paleomagnetic study of the Ryukyu arc. J Geophys Res 100:81698184. https://doi.org/10.1029/95JB00034

Murauchi S, Den N, Asano S, Hotta H, Yoshii T, Asanuma T, Hagiwara K, Ichikawa K, Sato T, Ludwig WJ, Ewing Jl, Edgar NT, Houtz RE (1968) Crustal structure in the Philippine Sea. J Geophys Res 73:3143-3171

Nakahigashi K, Shinohara M, Suzuki S, Hino R, Shiobara H, Takenaka H, Nishino M, Sato T, Yoneshima S, Kanazawa T (2004) Seismic structure of the crust and uppermost mantle in the incipient stage of back arc rifting — northernmost Okinawa Trough. Geophys Res Lett 31:L02614. https://doi. org/10.1029/2003GL018928

Nakamura M, Yoshida Y, Zhao D, Katao H, Nishimura S (2003) Three-dimensional P- and S-wave velocity structures beneath the Ryukyu arc. Tectonophysics 369:121-143

Narita H, Harada K, Tsunogai S (1990) Lateral transport of sediment particles in the Okinawa determined by natural radionuclides Trough. Geochem J 24:207-216

Nash DF (1979) The geological development of the north Okinawa trough area from Neogene times to Recent. J Jpn Assoc Pet Technol 44:121-133

Nishizawa A, Kaneda K, Katagiri Y, Oikawa M (2014) Wide-angle refraction experiments in the Daito Ridges region at the northwestern end of the Philippine Sea plate. Earth Planets Space 66:25. https://doi. org/10.1186/1880-5981-66-25

Nishizawa A, Kaneda K, Oikawa M, Horiuchi D, Fujiwara Y, Okada C (2017) Variations in seismic velocity distribution along the Ryukyu (NanseiShoto) Trench subduction zone at the northwestern end of the Philippine Sea plate. Earth Planets Space 69:86. https://doi.org/10.1186/ s40623-017-0674-7

Okamura N, Nishizawa A, Oikawa M, Horiuchi D (2017) Differential subsidence of forearc wedge of the Ryukyu (Nansei-Shoto) Arc caused by subduction of ridges on the Philippine Sea Plate. Tectonophysics 717:399-412

Ota Y, Machida H, Hori N, Konishi K, Omura A (1978) Holocene raised coral reefs of Kikai-jima (Ryukyu Islands) — an approach to Holocene sea level study- Geogr Rev Japan 51-2:109-130 (in Japanese with English abstract) 
Otsubo M, Yamaji A, Kubo A (2008) Determination of stresses from heterogeneous focal mechanism data: an adaptation of the multiple inverse method. Tectonophysics 457:150-160

Planke S, Rasmussen T, Rey SS, Myklebust R (2005) Seismic characteristics and distribution of volcanic intrusions and hydrothermal vent complexes in the Vøring and Møre basins. In: Doré AG, Vining BA (eds) Petroleum geology: north-western Europe and global perspectives-proceedings of the 6th Petroleum Geology Conference. Geological Society, London

Ruppel C (1995) Extensional processes in continental lithosphere. J Geophys Res 100:24187-24215. https://doi.org/10.1029/95JB02955

Shinjo R, Woodhead JD, Hergt JM (2000) Geochemical variation within the northern Ryukyu Arc: magma source compositions and geodynamic implications. Contrib Mineral Petrol 140:263-282

Sibuet J-C, Deffontaines B, Hsu S-K, Thareau N, Formal J-PL, Liu C-S, ACT party (1998) Okinawa trough backarc basin: early tectonic and magmatic evolution. J Geophys Res 103:30245-30267

ten Brink US, Ben-Avraham Z, Bell RE, Hassouneh M, Coleman DF, Andreasen G, Tibor G, Coakley B (1993) Structure of the Dead Sea pull-apart basin from gravity analyses. J Geophys Res 98:21877-21894

ten Veen JH, Kleinspehn KL (2002) Geodynamics along an increasingly curved convergent plate margin: late Miocene-Pleistocene Rhodes, Greece. Tectonics 21:1017

Terakawa T, Matsu'ura M (2010) The 3-D tectonic stress fields in and around Japan inverted from centroid moment tensor data of seismic events. Tectonics 29:6008. https://doi.org/10.1029/2009tc002626

The Headquarters for Earthquake Research Promotion (2016) Annual report on research project for the comprehensive evaluation of the information on off shore faults. http://www.jishin.go.jp/database/project_report/kaiikih27/. Accessed 1 Dec 2017 (in Japanese)
Tsuji T, Takai K, Oiwane H, Nakamura Y, Masaki Y, Kumagai H, Kinoshita M, Yamamoto F, Okano T, Kuramoto S (2012) Hydrothermal fluid flow system around the Iheya North Knoll in the mid-Okinawa trough based on seismic reflection data. J Volcanol Geother Res 213-214:41-50

von Huene R, Scholl DW (1991) Observation at convergent margins concerning sediment subduction, subduction erosion, and the growth of continental crust. Rev Geophys 29:279-316

Wallace LM, McCaffrey R, Beavan J, Ellis S (2005) Rapid microplate rotations and backarc rifting at the transition between collision and subduction. Geology 33:857-860. https://doi.org/10.1130/G21834.1

Wang Z, Huang R, Huang J, He Z (2008) P-wave velocity and gradient images beneath the Okinawa Trough. Tectonophysics 455:1-13

Wessel P, Smith WHF (1998) New improved version of the Generic Mapping Tools released. EOS Trans AGU 79:579

Woodcock NH, Fischer M (1986) Strike-slip duplexes. J Struct Geol 8:725-735

Yamaji A (2003) Slab rollback suggested by latest Miocene to Pliocene forearc stress and migration of volcanic front in southern Kyushu, northern Ryukyu Arc. Tectonophysics 364:9-24

Yokose H, Sato H, Fujimoto Y, Mirabueno HMT, Kobayashi T, Akimoto K, Yoshimura H, Morii Y, Yamawaki N, Ishii T, Honza E (2010) Mid-Pleistocene submarine acidic volcanism of the Tokara Islands, Japan. J Geogr 119:46-68 (in Japanese with English abstract)

\section{Submit your manuscript to a SpringerOpen ${ }^{\odot}$ journal and benefit from:}

- Convenient online submission

- Rigorous peer review

- Open access: articles freely available online

- High visibility within the field

- Retaining the copyright to your article

Submit your next manuscript at $\boldsymbol{\nabla}$ springeropen.com 